1. Hunt, J.F., Weaver, A.R., Landry, S.J., Gierasch, L. \& Deisenhofer, J. Nature 379, 37-45 (1996).

2. Mande, S.C., Mehra, V., Bloom, B.R. \& Hol, W.G.J. Science 271, 203-207 (1996).

3. Braig, K., Adams, P.D. \& Brnger, A.T. Nature Struct. Biology 2, 1083-1094 (1995).

4. Boisvert, D.C., Wang, J., Otwinowski. Z., Horwich, A.L. \& Sigler, P.B. Nature Struct. Biology 3, 170-177 (1996)

5. Van Dyk, T.K., Gatenby, A.A. \& LaRossa, R. Nature 342, 451-453 (1989)

6. Gordon, C.L., Sather, S.K., Casjens, S. \& King, J. J. Biol. Chem. 269, 27941-27951 (1994).

7. Schmidt, M., Buchner, J., Todd, M.J., Lorimer, G.H. \& Viitanen, P.V. J. Biol. Chem. 269, G.H. \& Viitanen, P.

8. Fayet, O., Zieglhofer, T. \& Georgopoulos, C. J. Bacteriol. 171, 1379-1385 (1989)

9. Landry, S.d., Zeilstra-Ryalls, J., Fayet, O., Georgopoulos, C. \& Gierasch, L. Nature 364, 255-258 (1993).

10. Martin, J., Geromanos, S., Tempst, P. \& Hartl, F.U. Nature 366, 279-282 (1993).

11. Todd, M.J., Boudkin, O., Freire, E. \& Lorimer, G.H. FEBS Lett. 359, 123-125 (1995).

12. Harris, J.R., Pluckthun, A. \& Zahn, R. J. Struct. Biol. 112, 216-230 (1994).

13. Llorca, O., Marco, S., Carrascosa, J.L. \& Valpuesta, J.M. FEBS Lett 345, 2-3(1994).

14. Schmidt, M. et al. Science 265, 656-659 (1994).

15. Langer, T., Pfeifer, G., Martin, J., Baumeister,
W. \& Hartl, F.U. EMBO J. 11, 4757-4765 (1992).

16. Chen, S. et al. Nature 371, 261-264 (1994)

17. Zeilstra-Ryalls, J., Fayet, O. \& Georgopoulos, C. J. Bacteriol. 176, 6558-656 (1994).

18. Rospert, 5. 1. Proc. Nati. Acad. Sci. USA 90 10967-10971 (1993)

19. Lubben, T.H., Gatenby, A.A., Donaldson, G.K., Lorimer, G.H. \& Viitanen, P.V. Proc. Nati Acad. Sci. USA 87, 7683-7687 (1990).

20. Bertsch, U., Soll, J., Seetharam, R. \& Viitanen, P.V. Proc. Nati. Acad. Sci. USA 89, 8696-8700 (1992).

21. van der Vies, S.M., Gatenby, A.A. \& Georgopoulos, C. Nature 368, 654-656 (1994).

22. Viitanen, P.V., Gatenby, A.A. \& Lorimer, G.H Prot. Sci. 1, 363-369.

23. Koonin, E.V. \& van der Vies, S.M. Trends in Biochem. 20, 14-15 (1995)

24. Saibil, H.R. et al. Curr. Biol. 3, 265-273 (1993).

25. Braig, K., Otwinowski, Z., Hegde, R Boisvert, D.C. Joachimiak, A., Horwich, A.L. \& Sigler, P.B. Nature 371, 578-586 (1994)

26. Viitanen, P.V. et al. Biochemistry 29 5665-5671 (1990).

27. Todd, M.J., Viitanen, P.V. \& Lorimer, G.H. Biochemistry 32, 8560-8567 (1993).

28. Gray, T.E. \& Fersht, A.R. FEBS Lett. 292. 254-258 (1991).

29. Todd, M.J., Viitanen, P.V. \& Lorimer, G.H.
Science 265, 659-666 (1994),

30. Yifrach, O. \& Horowitz, A. Biochemistry 34 5303-5308 (1995).

31. Kovalenko, O., Yifrach, O. \& Horowitz, A Biochemistry 33, 14974-14978 (1994).

32. Azem, A., Kessel, M. \& Goloubinoff, P. Science 265, 653-656 (1994).

33. Weissman, J.A. et al. Cel/ 83, 1-20 (1995)

34. Azem, A, Diamant, S., Kessel, M., Weiss, C. \& Goloubinoff, P. Proc. Natl. Acad. Sci. USA 92. 12021-12025 (1995).

35. Horovitz, A., Bochkareva, E.S., Kovalenko, O. \& Girshovich, A.S. J. Mol. Biol. 231, 58-64 (1993).

36. Luo, G.X. \& Horowitz, P.M I Biol Chem 269, 3215i-32154 (1994).

37. Viitanen, P.V., Lorimer, G.H., Seetharam, R. Gupta, R.S., Oppenheim, J., Thomas, J.O. \& Cowan, N.J. J. Biol.. Chem. 267, 695-698 (1992).

38. Todd, M.J., Walke, S., Lorimer, G.H., Truscott, K. \& Scopes, R.K. Biochemistry 34, $14932-19441$ (1995).

39. Hemmingsen, S.M. et al. Nature 333 330-334 (1988)

40. Hartman, D.J., Hoogenraad, N.J., Condron, R. \& Hj, P.B. Proc. Natl. Acad. Sci. USA 89, 3394-3398 (1992).

41. Rospert, S., Junne, T., Glick, B.S. \& Schatz, G. FEBS Lett. 335, 358-360

42. Yifrach, O., \& Horowitz, A. J. Mol. Biol. in the press (1996).

picture story

\title{
Probing the pore
}

Given the present difficulty of solving the structures of integral membrane proteins to anything near atomic reso-

lution alternative strategies for gleaning information on the structure, and therefore mode of action of these

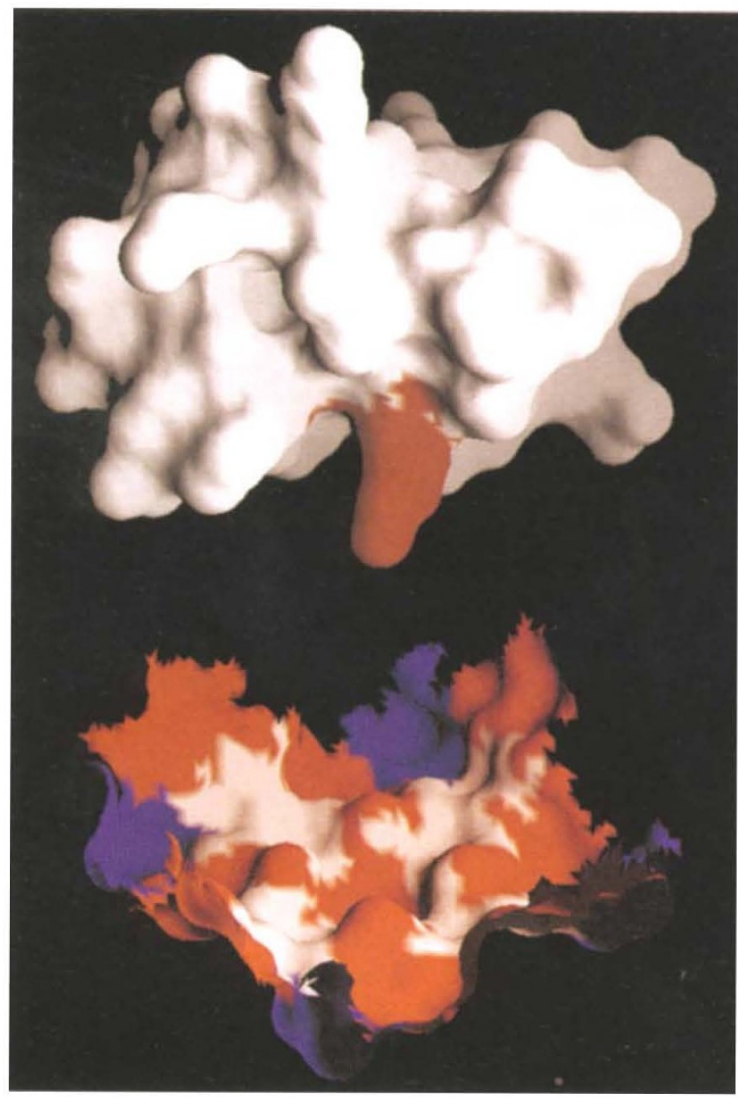
important molecules are much in demand. One strategy-applied to the Shaker voltage-gated $\mathrm{K}^{+}$ion channel-is presented by Rama Ranganathan, John H. Lewis and Roderick MacKinnon in Neuron 16, 1-20 (1996), the results of which are illustrated in the picture.

Protein-protein interaction surfaces are often highly complementary. Thus if the structure of one of the partners involved in the interaction is know it may be possible to use it as a reporter for the interacting surface of the other protein in the complex. The pore of the homotetrameric $\mathrm{K}^{+}$channel is selectively blocked (with 1:1 stoichiometry) by the peptide inhibitor AgiToxin2, found in scorpion venom. The atomic structure of the toxin is known and is shown in the upper image; the pore interaction surface is facing downwards with the residue Lys 27 highlighted in red.

MacKinnon and colleagues use the toxin as a probe of the conformation of the pore of the $\mathrm{K}^{+}$channel. The likely four-fold symmetric arrangement of the loops-have been shown to interact with the toxin-has enabled them to build a low-resolution model of the pore (lower image). Lys 27 is known to interact with ions in the channel and has been used as a constraint for the symmetry axis of the pore. The lower image shows the complement of a four-fold rotation of the inhibitor interaction surface about Lys 27 . The authors systematically characterise pairwise interactions between residues at the inhibitorchannel interface by combining scanning mutagenesis of the pore and toxin with thermodynamic mutant cycle analysis. The spatial distribution of the coupling energies between the mutated sites on the two proteins allows them to constrain the position of residues in the four identical pore-forming loops-one from each of the $\mathrm{K}^{+}$channel subunits. The results indicate that the loops fold to form a shallow vestibule (lower image). The structural determinants of ion-channel selectivity are found to be located centrally within the vestibule and very near the external solution.

GR 